\title{
Serological occurrence for tick-borne agents in beef cattle in the Brazilian Pantanal
}

\author{
Ocorrência sorológica para agentes transmitidos por carrapatos em \\ bovinos de corte no Pantanal Brasileiro
}

Inalda Angélica de Souza Ramos ${ }^{\text {; }}$ Victória Valente Califre de Mello; Natalia Serra Mendes ${ }^{1}$; Diego Carlos de Souza Zanatto'; João Bosco Vilela Campos²; João Vitor Almeida Alves²; Gabriel Carvalho de Macedo²; Heitor Miraglia Herrera²; Marcelo Bahia Labruna3; Gener Tadeu Pereira4; Rosangela Zacarias Machado1; Marcos Rogério André1* (1)

1 Departamento de Patologia Veterinária, Faculdade de Ciências Agrárias e Veterinárias, Universidade Estadual Paulista "Júlio de Mesquita Filho" - UNESP, Jaboticabal, SP, Brasil

2 Departamento de Parasitologia Veterinária, Universidade Católica Dom Bosco, Campo Grande, MS, Brasil

${ }^{3}$ Departamento de Medicina Veterinária Preventiva e Saúde Animal, Universidade de São Paulo, São Paulo, SP, Brasil

${ }^{4}$ Departamento de Ciências Exatas, Faculdade de Ciências Agrárias e Veterinárias, Universidade Estadual Paulista "Júlio de Mesquita Filho" - UNESP, Jaboticabal, SP, Brasil

How to cite: Sousa Ramos IA, Mello VVC, Mendes NS, Zanatto DCS, Campos JBV, Alves JVA, et al. Serological occurrence for tick-borne agents in beef cattle in the Brazilian Pantanal. Braz J Vet Parasitol 2020; 29(1): e014919. http://doi.org/10.1590/S1984-29612020007

\begin{abstract}
This study investigated the seropositivity for five different tick-borne agents, namely Anaplasma marginale, Babesia bovis, Babesia bigemina, Coxiella burnetii, Anaplasma phagocytophilum, and Trypanosoma vivax in beef cattle in the Brazilian Pantanal. The serum samples collected from animals (200 cows; 200 calves) were used in indirect enzyme-linked immunosorbent assays (iELISA) to detect IgG antibodies against $A$. marginale, B. bovis, B. bigemina, and T. vivax, and Indirect Fluorescent Antibody Test (IFAT) for detecting IgG antibodies against $C$. burnetii and A. phagocytophilum. No correlation was observed between seropositivity for C. burnetii and A. phagocytophilum with other agents whereas moderate correlation was observed for A. marginale $\times B$. bigemina $\times B$. bovis. Cows were more seropositive for $T$. vivax whereas calves were more seropositive for $B$. bovis and $B$. bigemina. The highest number of seropositive animals by a single agent was observed for T. vivax (15.2\%). Co-seropositivity for T. vivax $+A$. marginale was higher in cows (25.5\%) and for $T$. vivax $+B$. bovis + B. bigemina $+A$. marginale was higher in calves (57.5\%). The high seropositivity correlation for $A$. marginale $\times B$. bovis $\times B$. bigemina is probably due to the presence of the tick biological vector, Rhipicephalus microplus, in the studied farms. Common transmission pathways, mediated by hematophagous dipterans and fomites, may explain the high co-seropositivity of cows for A. marginale and $T$. vivax. Low seropositivity to C. burnetii is probably due to the type of breeding system employed (extensive). Seropositivity for A. phagocytophilum in only one animal suggests the occurrence of a cross-serological reaction with another agent of the genus Anaplasma.
\end{abstract}

Keywords: Trypanosomiasis, Anaplasmosis, Babesiosis, Q-Fever. 


\section{Resumo}

Este estudo teve como objetivo determinar a co-soropositividade para agentes transmitidos por carrapatos, como Anaplasma marginale, Babesia bovis, Babesia bigemina, Coxiella burnetii, Anaplasma phagocytophilum, e Trypanosoma vivax em bovinos de corte do Pantanal Brasileiro. Amostras de soro foram colhidas de 400 animais (200 vacas; 200 bezerros) e submetidas a Ensaios Imunoenzimáticos Indiretos (iELISA) para detecção de anticorpos IgG anti- A. marginale, anti- B. bovis, anti- B. bigemina e anti- $T$. vivax, e à Reação de Imunofluorescência Indireta (RIFI) para detecção de anticorpos IgG anti-C. burnetii e anti- A. phagocytophilum. Ausência de correlação foi vista entre os animais soropositivos para $C$. burnetii e $A$. phagocytophilum com os outros agentes e correlação moderada ocorreu entre $A$. marginale $\times B$. bigemina $\times$ B. bovis. Vacas foram mais soropositivas que bezerros para $T$. vivax e bezerros mais soropositivos que vacas para $B$. bovis e $B$. bigemina. Maior número de animais soropositivos para um único agente foi visto para $T$. vivax (15,2\%). Vacas demonstraram maior co-soropositividade para T. vivax + A. marginale $(25,5 \%)$ e bezerros para $T$. vivax + B. bovis + B. bigemina $+A$. marginale $(57,5 \%)$. A alta correlação entre a soropositividade para $A$. marginale $\mathrm{x}$ $B$. bovis $\times$ B bigemina é provavelmente devida à presença do vetor biológico, o carrapato Rhipicephalus microplus, nas fazendas estudadas. As vias de transmissão comuns, mediadas por dípteros hematófagos e fômites, podem explicar a alta co-soropositividade das vacas para A. marginale e T. vivax. A baixa soropositividade para C. burnetii é provavelmente devida ao tipo de sistema de criação empregado (extenso). A soropositividade para A. phagocytophilum em apenas um animal sugere a ocorrência de reação sorológica cruzada com outro agente do gênero Anaplasma.

Palavras-chave: Tripanossomose, Anaplasmose, Babesiose, Febre Q.

\section{Introduction}

The Brazilian Pantanal plays an important role in the national economy due to beef cattle production and is also described as one of the most biologically diverse regions in the world (Myers et al., 2000; Alho, 2005). The human occupation of the Pantanal has introduced exotic animals and plants that changed the ecosystem, thus favoring the dissemination of pathogens among the native fauna (Alho, 2005; Fantin-Cruz, 2008). The relationship between hosts, parasites, and the environment when disharmonious can cause an onset of diseases (Herrera et al., 2007). According to Guimarães et al. (2001), ticks are one of the most important ectoparasites and pathogen vectors for farmed animals in the Pantanal region, keeping a close relationship with the changing environmental conditions.

Moreover, beef cattle production in the Pantanal has been changing, resulting in increasing cattle density and replacement of native vegetation cover with exotic grasses. Consequently, the growing contact between domestic animals and native fauna also increases the exchange of pathogens (Cançado et al., 2008). Anaplasma marginale, Babesia bovis, Babesia bigemina, Coxiella burnetii, Trypanosoma vivax and Anaplasma phagocytophilum infections can cause serious diseases in cattle and are mainly transmitted by arthropod vectors (Maurin \& Raoult, 1999; Fereig et al., 2017). Tick-borne diseases are an important factor affecting livestock production in tropical and subtropical regions worldwide, with considerable economic losses (Marcelino et al., 2012).

Anaplasma marginale is an intra-erythrocyte bacterium that has an economic impact on endemic countries, especially due to the high morbidity and mortality in susceptible cattle herds. Losses result from low weight gain, reduced milk yield, abortion, treatment costs and mortality (Kocan et al., 2003). Brazil is endemic for A. marginale, with a molecular prevalence in domestic ruminants varying from $7.5 \%$ to close to or equal to $100 \%$ (Silva et al., 2016). Bovine babesiosis is a hemoparasitosis caused by the protozoa Babesia bovis and Babesia bigemina, which cause fever, anemia, anorexia, lethargy, hemoglobinuria, and muscle tremors (Singh et al., 2009). This disease is also economically important due to the high morbidity and mortality of animals, especially among calves, and its effects on weight gain and milk yield, requiring expensive control and prevention measures. Trypanosoma vivax can cause hematological and nervous changes in cattle, as well as abortions and other reproductive disorders (Silva et al., 1996; Batista et al., 2007). 
Coxiella burnetii is an obligate intracellular bacterium that can cause reproductive disorders in ruminants and $\mathrm{Q}$ fever in humans. Ruminants are the main source for C. burnetii, being responsible for zoonotic outbreaks in several countries (Maurin \& Raoult, 1999; Georgiev et al., 2013; OIE, 2018). Anaplasma phagocytophilum is a Gram-negative obligate intracellular bacterium that replicates in neutrophilic granulocytes, causing tick-borne fever in sheep and cattle, and granulocytic anaplasmosis in dogs, horses, cats, and humans (Dumler et al., 2001; Carrade et al., 2004; Atif, 2015; Ismail \& McBride, 2017; Lappin, 2018; Saleem et al., 2018). The main vectors are ticks of the Ixodes complex (I. ricinus, I. scapularis, I. pacificus, I. persulcatus, and I. spinipalpis) (Stuen et al., 2013).

This work investigated the serological occurrence of $A$. marginale, B. bovis. B. bigemina, C. burnetii, A. phagocytophilum and T. vivax in beef cattle in the Brazilian Pantanal.

\section{Material and Methods}

\section{Animals and study area}

The sampled beef cattle (Bos taurus indicus) herds were reared in an extensive farming system in five different farms located in the Central Region of the Pantanal Sul Matogrossense, Sub-Region of Nhecolândia. The blood samples were collected from 400 animals ( 200 cows and 200 calves) for a cross-sectional study approved by the National Council for Animal Experimentation Control (CONCEA) and the Ethics Committee on Animal Use (CEUA, FCAV, UNESP, Protocol No. 12375/15). All four sampled farms had animals infested with ticks, Rhipicephalus microplus and Amblyomma sculptum, which were previously identified using already described taxonomic keys (Martins et al., 2010). Some animals presented co-infestation by two or more tick species. Hematophagous dipterans, such as horn flies (Haematobia irritans) and tabanids (Tabanus spp.) were also observed (Souza Ramos et al., 2019a, b; Mendes et al., 2019; De Mello et al., 2019).

\section{Bovine serum sampling}

Whole blood samples collected directly from the caudal vein and stored in $10 \mathrm{~mL}$ tubes were centrifuged at $2000 \times \mathrm{g}$ for 10 minutes to separate the sera. Serum aliquots were distributed in $2 \mathrm{~mL}$ microtubes and stored at $-20^{\circ} \mathrm{C}$ until further serological tests.

\section{Indirect enzyme-linked immunosorbent assay (iELISA) for detecting IgG antibodies against $A$. marginale, $B$. bovis, $B$. bigemina and $T$. vivax}

The antibodies against $B$. bovis and $B$. bigemina were detected by the indirect ELISA technique (iELISA) following the protocol described by Machado et al. (1997), whereas the detection of antibodies to $A$. marginale followed the technique adapted by Andrade et al. (2004). The A. marginale, B. bovis and B. bigemina total antigens were produced by the Immunodot diagnoses Ltda. (Imunodot Desenvolvimento, Indústria e Comércio de Imunógenos e Produtos de Diagnóstico Veterinários, Jaboticabal, SP), at the optimum concentration of $10 \mu \mathrm{g} / \mathrm{mL}$, diluted in $0.5 \mathrm{M}$ bicarbonate carbonate buffer and $\mathrm{pH}$ 9.6. The presence of IgG antibodies against $T$. vivax was evaluated following the modified methodology established by Aquino et al. (1999). The T. vivax total antigen was produced in the Laboratory of Immunoparasitology of the Universidade Estadual Paulista (UNESP/FCAV, Jaboticabal, SP) (González et al., 2005) at an optimum concentration of $0.1 \mu \mathrm{g} / \mathrm{mL}$, also diluted in $0.5 \mathrm{M}$ bicarbonate carbonate buffer and $\mathrm{pH}$ 9.6. After incubation at $4{ }^{\circ} \mathrm{C}$ for 12 hours, a blockade was performed using PBS Tween $20(\mathrm{pH} 7.2)$ with added $6 \%$ milk powder (Molico ${ }^{\circledR}$, Nestlé, Brazil). The plates (Maxisorp ${ }^{\circledR}$; Nunc, Thermo Scientific, Brazil) were incubated in a moist chamber at $37^{\circ} \mathrm{C}$ for 90 minutes. After three washings with PBS-Tween 20 buffer, the positive and negative reference serum and tested serum samples, previously diluted with PBS-Tween 20 solution plus $5 \%$ normal Rabbit serum at the following dilutions 1:400 (A. marginale, B. bovis and B. bigemina) and 1:100 (T. vivax) 
according to Sampaio et al. (2015), were added to the ELISA plates. The plates were incubated again at $37{ }^{\circ} \mathrm{C}$ for 90 minutes. After three washes with PBS-tween 20 buffer, the bovine conjugated IgG (Sigma ${ }^{\circledR}$, St. Louis, USA) was added to the ELISA plate, in the 1:30000 dilution in PBS-tween 20 plus $5 \%$ of normal rabbit serum, with subsequent incubation and washing. Finally, the substrate of the alkaline phosphatase enzyme, P-nitrophenyl phosphate (Sigma ${ }^{\circledR}$, St. Louis, MO, USA) diluted at $1 \mathrm{mg} / \mathrm{mL}$ in diethanolamine buffer $\mathrm{pH} 9.8$ (Sigma ${ }^{\circledR}$, St. Louis, USA) was added. The iELISA plates were sealed with aluminum foil and incubated at room temperature for 30 minutes for $A$. marginale, B. bovis and B. bigemina and during 45 minutes for $T$. vivax. The reading was performed in an ELISA reader (B.T.-100; Embrabio, São Paulo, Brazil), with a $405 \mathrm{~nm}$ filter. The cutoff values, calculated as 2.5 times the mean absorbance of the negative control sera (Machado et al., 1997), were as follows 0.248 for B. bovis; 0.256 for B. bigemina; 0.190 for A. marginale; and 0.298 for $T$. vivax.

\section{Indirect Fluorescent Antibody Test (IFAT) for detecting IgG antibodies against C. burnetii and A. phagocytophilum}

Detection of IgG antibodies against $C$. burnetii was performed using the crude antigen of the C. burnetii At12 strain (Pacheco et al., 2013; Reeves et al., 2006). Serum samples from cattle previously known to be seropositive and/or seronegative for such antigen were used as control (Zanatto et al., 2019a). Detection of IgG antibodies against A. phagocytophilum used the crude antigen obtained from HL-60 cells infected with the Webster strain of $A$. phagocytophilum, courtesy of Dr. John Stephen Dumler (Uniformed Services University of the Health Sciences, Bethesda, Maryland, USA) (Scorpio et al., 2004). The positive control sample for A. phagocytophilum (1:2560 titer) was obtained from an equine experimentally infected with the Webster strain of $A$. phagocytophilum in the Department of Veterinary Pathology, UNESP, Jaboticabal, SP, Brazil. Serum samples from healthy cattle were used as negative controls (Sousa et al., 2013). Serum samples were first diluted to 1:64 (C. burnetii) and 1:80 (A. phagocytophilum) in phosphate-buffered saline solution (PBS) (pH 7.2; $\mathrm{NaCl} 1.3 \mathrm{M}, \mathrm{KCl} 27 \mathrm{M}, \mathrm{Na}_{2} \mathrm{HPO}_{4} 56 \mathrm{mM}, \mathrm{KH}_{2} \mathrm{PO}_{4} 10 \mathrm{mM}$, and $\mathrm{NaH}_{2} \mathrm{PO}_{4} 9.2 \mathrm{mM}$ ). After dilution, $20 \mu \mathrm{L}$ and $10 \mu \mathrm{L}$ serum aliquots were placed in each well of the slides containing antigens against $C$. burnetii and $A$. phagocytophilum, respectively, with posterior incubation in a moist chamber at $37^{\circ} \mathrm{C}$ for 30 minutes. After incubation, the slides were washed three times with a wash buffer (phosphate-buffered saline, PBS $\mathrm{pH} 7.4+1 \%$ Triton $+1.5 \mathrm{~mL}$ of Evans Blue) for five minutes, consecutively, and then dried at room temperature. Then, $20 \mathrm{~mL}$ conjugated anti-bovine IgG diluted to 1:200 and marked by Fluorescein isothiocyanate (Sigma-Aldrich ${ }^{\circledR}$, St. Louis, Missouri, United States) was added to the slides with $C$. burnetti antigens and $10 \mathrm{~mL}$ conjugated goat anti-horse IgG diluted to 1:64, also marked with fluorescein isothiocyanate (SIGMA ${ }^{\circledR}$, St. Louis, Missouri, United States), was added to the slides with A. phagocytophilum antigen. The last incubation in a moist chamber at $37^{\circ} \mathrm{C}$ for 30 minutes was followed by subsequent washing, as previously described. After the slides were left to dry at room temperature, buffered glycerin was added (glycerin and carbonate-bicarbonate buffer $0.5 \mathrm{M}, \mathrm{pH}$ 9.6), the slides were covered with laminules and observed under a microscope equipped with fluorescent light and at 400X magnification (Olympus BX-FLA ${ }^{\circledR}$, Tokyo, Japan).

\section{Statistical analysis}

The correlation between seropositivity for the several investigated agents was estimated by the Pearson Correlation Index (c), using the software The R Project for Statistical Computing ( $R$ version 3.4.4). The frequency of co-seropositivity for more than one agent in cows and calves and between male and female calves was analyzed by Chi-Square $\left(x^{2}\right)$ and Fisher exact test. $P$ values $<0.05$ were considered statistically significant for one of the categories. In order to check the dependence between seropositive animals and farms, the Chi-square test $\left(\mathrm{x}^{2}\right)$ and Fisher's exact test were used, with $\mathrm{P}<0.05$. 


\section{Results}

The occurrence of antibodies to the selected tick-borne agents and T. vivax is shown in Table 1 . The Chi-Square $\left(x^{2}\right)$ test showed that $T$. vivax seropositivity was higher in cows compared to calves $(P<0.05)$ while $B$. bovis and $B$. bigemina seropositivity was higher for calves $(P<0.05)$. There was no statistical difference $(P>0.05)$ between the categories for A. marginale in the Chi-square test. Furthermore, Fisher's exact test indicated no statistical difference for $C$. burnetii and A. phagocytophilum between the two categories, cows and calves. All results are shown in Table 1.

Table 1. Differences in the seropositivity of cows and calves for $T$. vivax, A. marginale, B. bovis, $B$. bigemina, C. burnetii and $A$. phagocytophilum, using the Chi-square test $\left(x^{2}\right)$.

\begin{tabular}{|c|c|c|}
\hline Infectious Agents & Cows & Calves \\
\hline T. vivax & $98.5 \%(197 / 200)^{A}$ & $83.5 \%(167 / 200)$ в \\
\hline C. burnetii* & $1 \%(2 / 200)^{A}$ & $0 \%(0 / 200)^{A}$ \\
\hline B. bovis & $50 \%(100 / 200)^{\mathbf{B}}$ & $72.5 \%(145 / 200)^{A}$ \\
\hline B. bigemina & $34.5 \%(69 / 200)^{\text {B }}$ & $68 \%(136 / 200)^{A}$ \\
\hline A. marginale & $77 \%(154 / 200)^{A}$ & $67.5 \%(135 / 200)^{A}$ \\
\hline A. phagocytophilum* & $0.5 \%(1 / 200)^{A}$ & $0 \%(0 / 200)^{A}$ \\
\hline
\end{tabular}

Different capital letters overwritten in bold (A and $B)$ in the same line indicate statistical difference regarding seropositivity between cows and calves for a given agent by the Chi-square test $\left(x^{2}\right)$, where $(A>B)$. Equal uppercase letters overwritten in bold ( $A$ and $B$ ) on the same line indicate no statistical difference. *: Regarding the seropositivity for these agents, Fisher's exact test was used.

The Pearson Index (c) showed no correlation between the seropositivity for $C$. burnetii and $A$. phagocytophilum and the presence of antibodies to the other investigated agents, whereas a moderate correlation was observed for the seropositivity for $A$. marginale $\mathrm{x}$ B. bigemina $\times$ B. bovis (Table 2).

Table 2. Correlation (c) of seropositive animals for T. vivax, A. marginale, B. bovis, B. bigemina, C. burnetii and $A$. phagocytophilum among the 400 cattle sampled in the Brazilian Pantanal.

T. vivax C. burnetii B. bovis B. bigemina A. marginale

\begin{tabular}{|c|c|c|c|c|c|c|}
\hline T. vivax & - & 0.01 & 0.17 & 0.15 & 0.21 & 0.01 \\
\hline C. burnetii & & - & -0.01 & -0.0 & -0.03 & -0.00 \\
\hline B. bovis & & & - & 0.51 & 0.38 & 0.03 \\
\hline B. bigemina & & & & - & 0.52 & -0.05 \\
\hline
\end{tabular}

\section{A.} 0.03

\section{A. phagocytophilum}

\section{Numbers represent values of " $\mathrm{c}$ " according to Pearson's correlation coefficient \\ Seropositivity for a single agent was higher for T. vivax (16\%; 32/200 cows and 14.5\%; $29 / 200$ calves) while no animal was seropositive for only B. bovis, C. burnetii and/or A. phagocytophilum. In cows, co-seropositivity was higher for T. vivax + A. marginale (25.5\%; 51/200; $\mathrm{P}<0.05)$ followed by $T$. vivax $+B$. bovis $+B$. bigemina + A. marginale $(25 \% ; 50 / 200)$. However, in calves, co-seropositivity was higher for the four last agents $(57.5 \% ; 115 / 200$;}


$P<0.05)$. Only one cow $(0.5 \% ; 1 / 200)$ was seropositive for all studied agents (Table 3 ). Additionally, co-seropositivity for B. bigemina was higher for female calves compared to males $(P<0.05)$.

Table 3. Co-seropositivity for A. marginale, A. phagocytophilum, B. bovis, B. bigemina, C. burnetii and T. vivax among the 400 sampled beef cattle (200 cows and 200 calves) in the Brazilian Pantanal.

\begin{tabular}{|c|c|c|}
\hline Agents & Cows & Calves \\
\hline Anaplasma marginale (Am) & - & $0.5 \%(1 / 200)$ \\
\hline Anaplasma phagocytophilum (A.p.) & - & - \\
\hline Babesia bovis (B.bo.) & - & - \\
\hline Babesia bigemina (B.bi) & & $1.5 \%(3 / 200)$ \\
\hline Coxiella burnetii (C.b.) & - & - \\
\hline Trypanosoma vivax (T.v.) & $16 \%(32 / 200)$ & $14.5 \%(29 / 200)$ \\
\hline T.v. + A.m. & $25.5 \%(51 / 200) \mathrm{A}$ & $1.5 \%(3 / 200) \mathrm{B}$ \\
\hline T.v. + B.bo. & $4.5 \%(9 / 200)$ & $8 \%(16 / 200)$ \\
\hline T.v. B.bi. & $1 \%(2 / 200)$ & $0.5 \%(1 / 200)$ \\
\hline B.bo. + A.m. & $0.5 \%(1 / 200)$ & - \\
\hline T.v. + C.b. & $0.5 \%(1 / 200)$ & - \\
\hline B.bi. + A.m. & - & $1.5 \%(3 / 200)$ \\
\hline T.v. + B.bo. + A.m. & $18 \%(36 / 200) A$ & $2 \%(4 / 200) B$ \\
\hline T.v. + B.bi. + A.m. & $7 \%(14 / 200)$ & $4.5 \%(9 / 200)$ \\
\hline T.v. + B.bo. + B.bi. & - & $3.5 \%(7 / 200)$ \\
\hline T.v. + B.bo. + B.bi. + A.m & $25 \%(50 / 200) B$ & $57.5 \%(115 / 200) \mathrm{A}$ \\
\hline T.v + B.bo. + A.m + A.p & $0.5 \%(1 / 200)$ & - \\
\hline T.v. + B.bo. + B.bi. + A.m $m+$ C.b. & $0.5 \%(1 / 200)$ & - \\
\hline
\end{tabular}

Chi-square $\left(x^{2}\right)$ and Fisher's exact tests demonstrated the existence of significant dependence between the number of seropositive animals for the studied agents and the farms where beef cattle were sampled. Seropositive calves showed significant dependence on both general and comparative farms $(P<0.05)$. Seropositivity for A. marginale was detected in all properties studied, but there was no statistical difference between FPA vs FNH; FA vs FC; FA vs FPA e FPA vs FNH. The presence of anti-B. bovis and $B$. bigemina antibodies in calves were statistically more frequent and significant in relation to farms in comparison FA vs FNH; FA vs FPA; FPA vs FNH. None of the farms presented seropositive calves for $C$. burnetii and A. phagocytophilum ( $\mathrm{P}>0.05$ ). For $T$. vivax, a higher statistical dependence was found when comparing seropositive calves from farms FA vs FC e FA vs FPA. These results can be seen in Tables 4 and 5 and Figure 1. 
Table 4. Seropositivity of calves for T. vivax, A. marginale, B. bovis, B. bigemina, C. burnetii and A. phagocytophilum and their dependence on the five analyzed farms.

\begin{tabular}{|c|c|c|c|c|c|c|c|}
\hline \multirow[b]{2}{*}{ Agents } & \multicolumn{7}{|c|}{ Farms } \\
\hline & & FA & FC & FNH & FPA & FSJ & $P$-value \\
\hline \multirow{2}{*}{ A. marginale } & POSITIVE & 49 & 30 & 24 & 2 & 30 & \multirow{2}{*}{$<2.2^{-16}$} \\
\hline & NEGATIVE & 4 & 1 & 10 & 39 & 11 & \\
\hline \multirow{2}{*}{ B. bovis } & POSITIVE & 53 & 21 & 19 & 16 & 36 & \multirow{2}{*}{$8.415^{-11}$} \\
\hline & NEGATIVE & 0 & 10 & 15 & 25 & 5 & \\
\hline \multirow{2}{*}{ B. bigemina } & POSITIVE & 49 & 28 & 23 & 2 & 34 & \multirow{2}{*}{$<2.2^{-16}$} \\
\hline & NEGATIVE & 4 & 3 & 11 & 39 & 7 & \\
\hline \multirow{2}{*}{ T. vivax } & POSITIVE & 49 & 27 & 31 & 26 & 34 & \multirow{2}{*}{0.002073} \\
\hline & NEGATIVE & 4 & 4 & 3 & 15 & 7 & \\
\hline \multirow{2}{*}{ C. burnetii } & POSITIVE & - & - & - & - & - & \multirow{2}{*}{0.1257} \\
\hline & NEGATIVE & 53 & 31 & 34 & 41 & 41 & \\
\hline \multirow{2}{*}{ A. phagocytophilum } & POSITIVE & - & - & - & - & - & \multirow{2}{*}{0.1257} \\
\hline & NEGATIVE & 53 & 31 & 34 & 41 & 41 & \\
\hline
\end{tabular}

FA: Alegria Farm; FSJ: São João Farm; FPA: Porto Alegre Farm; FNH: Novo Horizonte Farm; FC: Caceres Farm; $P$-values $<0.05$ are considered significant by Chi-square $\left(X^{2}\right)$ and Fisher's exact tests.

Table 5. Seropositivity of calves for T. vivax, A. marginale, B. bovis, B. bigemina, C. burnetii and A. phagocytophilum and their dependence on the comparison of the five analyzed farms, represented by $P$-value.

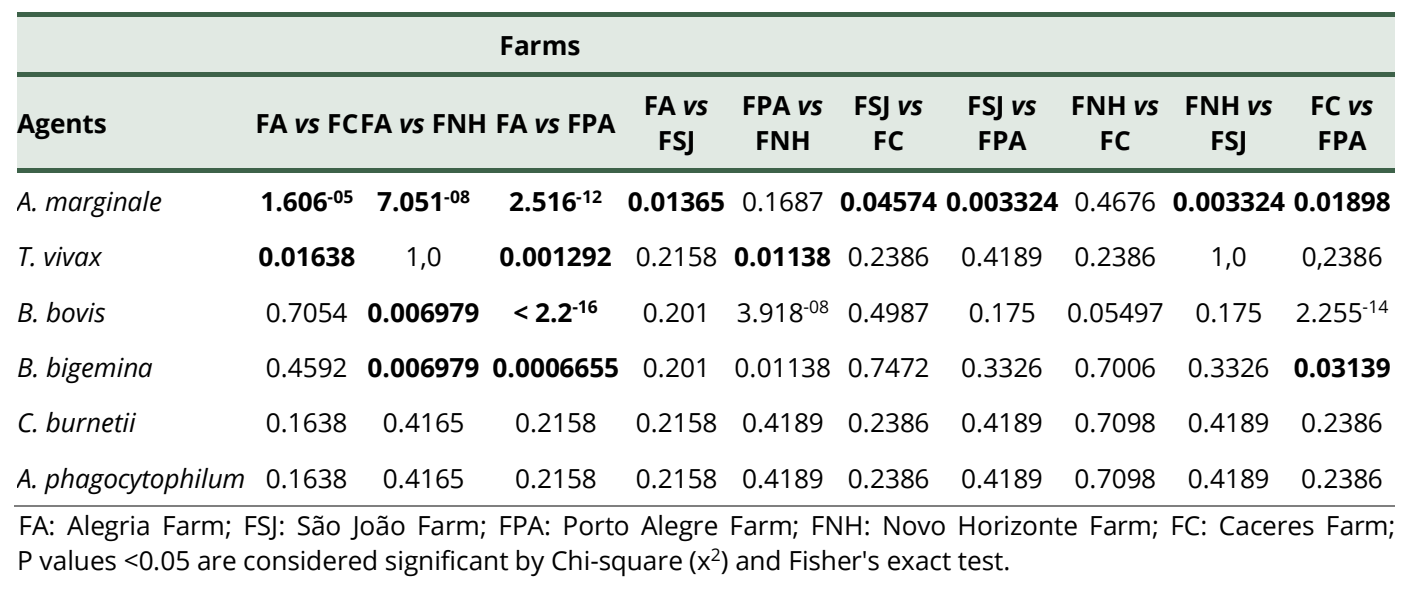



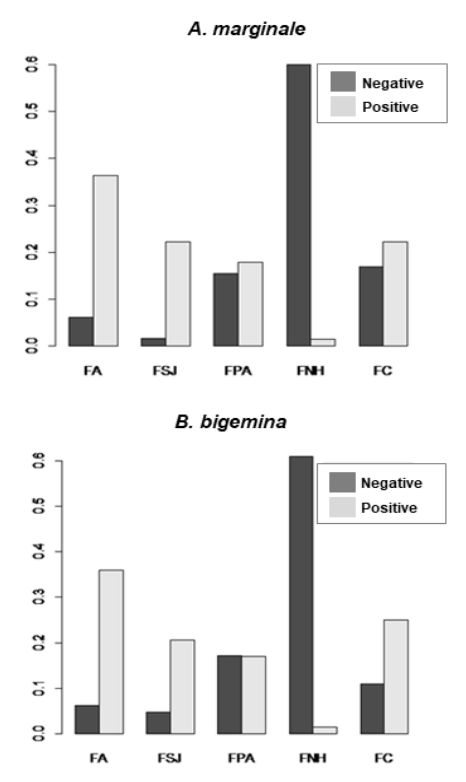
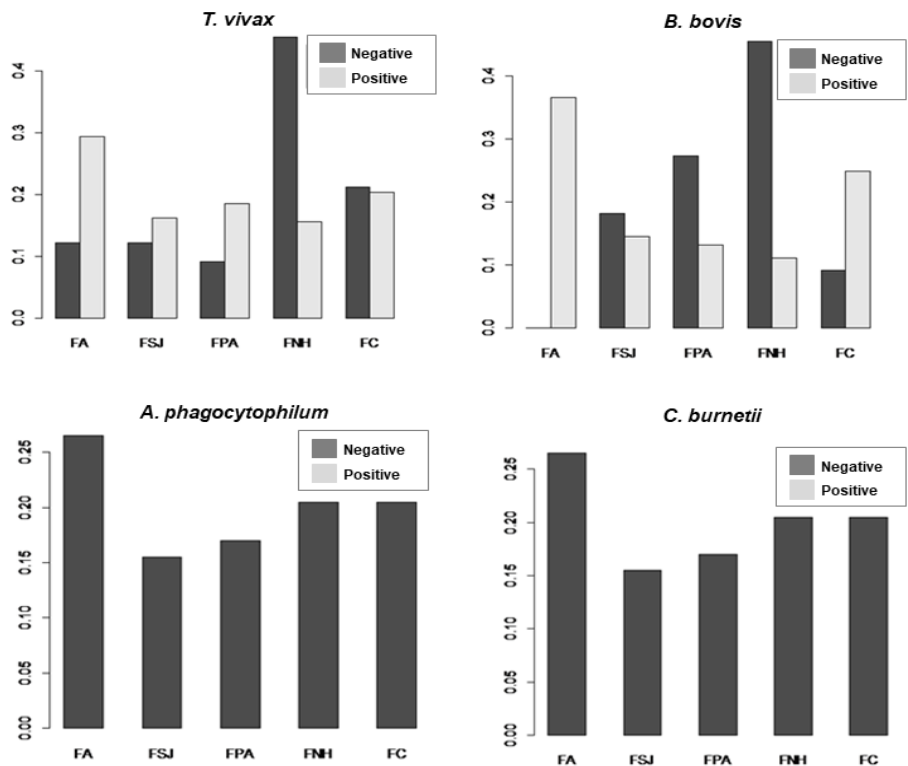

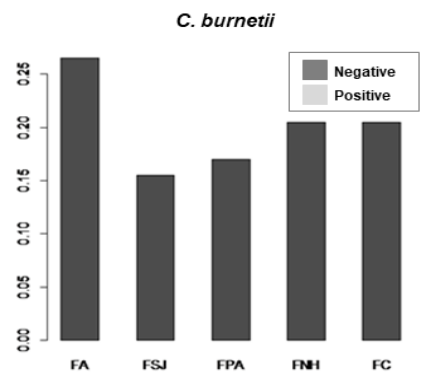

Figure 1. Seropositive and seronegative calves for the six agents studied according to the farms analyzed. Blank columns represent seropositive animals and black columns seronegative animals.

The seropositivity of cows for A. marginale, B. bovis and B. bigemina showed significant statistical dependence both in the general comparison of farms and in the comparison of farms to each other $(P<0.05)$. Regarding the seropositivity of cows for $B$. bovis, a higher dependence relationship was observed when the comparisons were performed taking into account two farms at each time. On the other hand, seropositivity for B. bigemina only showed significant dependence between FC vs FPA farms. There was no statistically significant difference in $T$. vivax seropositivity among the analyzed farms, since the seropositivity for this agent was high in the five sampled farms. A single cow was seropositive for $A$. phagocytophilum on Alegria Farm, whereas two others were seropositive for $C$. burnetii on Porto Alegre and Novo Horizonte farms, respectively. Due to the low number of seropositive animals to A. phagocytophilum and C. burnetii, there was no significant difference between the analyzed farms (Tables 6 and 7; Figure 2). 
Table 6. Seropositivity of calves for T. vivax, A. marginale, B. bovis, B. bigemina, C. burnetii and $A$. phagocytophilum and their dependence on the five analyzed farms.

\begin{tabular}{|c|c|c|c|c|c|c|c|}
\hline \multirow{2}{*}{ Agents } & \multicolumn{7}{|c|}{ Farms } \\
\hline & & FA & FC & FNH & FPA & FSJ & $P$-value \\
\hline \multirow{2}{*}{ A. marginale } & POSITIVE & 44 & 32 & 30 & 13 & 35 & \multirow{2}{*}{$3.123^{-11}$} \\
\hline & NEGATIVE & 1 & 4 & 8 & 26 & 7 & \\
\hline \multirow{2}{*}{ T. vivax } & POSITIVE & 45 & 36 & 37 & 37 & 42 & \multirow{2}{*}{0.1773} \\
\hline & NEGATIVE & 0 & 0 & 1 & 2 & 0 & \\
\hline \multirow{2}{*}{ B. bigemina } & POSITIVE & 17 & 25 & 20 & 5 & 2 & \multirow{2}{*}{$4.084^{-10}$} \\
\hline & NEGATIVE & 28 & 11 & 18 & 34 & 40 & \\
\hline \multirow{2}{*}{ B. bovis } & POSITIVE & 32 & 20 & 17 & 19 & 12 & \multirow{2}{*}{0.002018} \\
\hline & NEGATIVE & 13 & 16 & 21 & 20 & 30 & \\
\hline \multirow{2}{*}{ C. burnetii } & POSITIVE & - & - & 1 & 1 & - & \multirow{2}{*}{0.411} \\
\hline & NEGATIVE & 45 & 36 & 37 & 38 & 42 & \\
\hline \multirow{2}{*}{ A. phagocytophilum } & POSITIVE & 1 & - & - & - & - & \multirow{2}{*}{1.0} \\
\hline & NEGATIVE & 44 & 36 & 38 & 39 & 42 & \\
\hline
\end{tabular}

FA: Alegria Farm; FSJ: São João Farm; FPA: Porto Alegre Farm; FNH: Novo Horizonte Farm; FC: Caceres Farm; $P$ values $<0.05$ are considered significant by Chi-square $\left(x^{2}\right)$ and Fisher's exact tests.

Table 7. Seropositivity of calves for T. vivax, A. marginale, B. bovis, B. bigemina, C. burnetii and A. phagocytophilum and their dependence on the comparison of the five analyzed farms, represented by $P$-value.

\begin{tabular}{|c|c|c|c|c|c|c|c|c|c|c|}
\hline \multicolumn{11}{|c|}{ Farms } \\
\hline Agents & FA vs FC & $\begin{array}{l}\text { FA vs } \\
\text { FNH }\end{array}$ & $\begin{array}{l}\text { FA vs } \\
\text { FPA }\end{array}$ & FA vs FSJ & $\begin{array}{l}\text { FNH vs } \\
\text { FPA }\end{array}$ & $\begin{array}{l}\text { FSJ vs } \\
\text { FC }\end{array}$ & $\begin{array}{l}\text { FSJ vs } \\
\text { FPA }\end{array}$ & $\begin{array}{l}\text { FC vs } \\
\text { FPA }\end{array}$ & $\begin{array}{l}\text { FC vs } \\
\text { FNH }\end{array}$ & $\begin{array}{l}\text { FNH } \\
\text { vs FS J }\end{array}$ \\
\hline A. marginale & 0.1679 & 0.02448 & 0.04529 & $9.956^{-5}$ & 0.8205 & 0.02131 & 0.1652 & 0.01898 & 0.4446 & 0.175 \\
\hline T. vivax & 1.0 & 0.4578 & 0.4643 & 1.0 & 1.0 & 1.0 & 0.475 & 0.2386 & 0.7006 & 1.0 \\
\hline B. bovis & 0.007014 & 0.1915 & 0.0126 & 0.000185 & 0.0002325 & $9.348^{-10}$ & $\begin{array}{c}1.887 \mathrm{e}- \\
06\end{array}$ & $2.255^{-14}$ & 0.03548 & 0.175 \\
\hline B. bigemina & 1.0 & 0.4578 & 0.2126 & 1.0 & 1.0 & 1.0 & 0.475 & 0.03139 & 0.2386 & 0.3326 \\
\hline C. burnetii & 1.0 & 1.0 & 1.0 & 1.0 & 1.0 & 1.0 & 1.0 & 0.2386 & 0.7098 & 0.4189 \\
\hline A. phagocytophilum & 1.0 & 1.0 & 1.0 & 1.0 & 1.0 & 1.0 & 1.0 & 1.0 & 1.0 & 1.0 \\
\hline
\end{tabular}



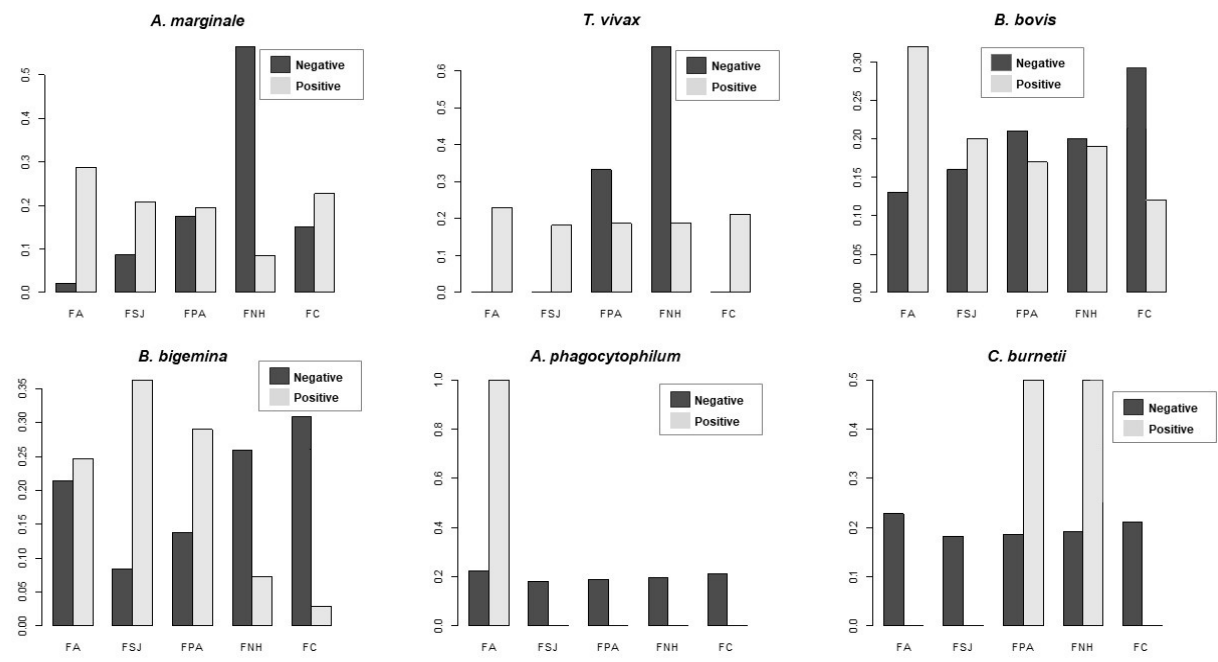

Figure 2. Seropositive and seronegative cows for the six agents studied according to the analyzed farms. Blank columns represent seropositive animals and black columns seronegative animals.

\section{Discussion}

In Brazil, the expanding geographic distribution of $T$. vivax has resulted from the livestock moving between endemic regions and those where the conditions are favorable (climate favorable to hematophagous dipterans, animals lacking prior immunity to the parasite, and the permanent practice of sharing blood-contaminated needles [fomites] during vaccination and application of oxytocin) (Cadioli et al., 2012; Bastos et al., 2017; Andrade Neto et al., 2019). The results showed that cows are significantly more exposed to $T$. vivax compared to calves, which may be related to the longer period in contact with hematophagous mechanical vectors and fomites (especially due to shared needles). Hematophagous dipterans (horn and horse flies) were also observed in significant numbers in the sampled properties.

The iELISA results indicated a high occurrence for $A$. marginale in the studied region. In the Brazilian territory, this pathogen occurrence in domestic ruminants estimated by iElisa can range from $16.3 \%$ in the semiarid Sergipe to close to $100 \%$ in Minas Gerais, Paraíba, Bahia, Paraná, Pará, Rio de Janeiro, São Paulo, and Goiás, being considered an endemic agent in Brazil (Oliveira et al., 2013; Silva et al., 2016). Calves and cows were also exposed to $A$. marginale, due to the constant presence of the tick Rhipicephalus microplus, considered a biological vector, and hematophagous dipterans parasitizing both. cows and calves. Additionally, the transplacental transmission may also have contributed to the herd seropositivity, but the occurrence of this transmission mode has not been confirmed among the studied animals. The co-seropositivity for $T$. vivax $\times$ A. marginale was highest among cows, which remained for a longer period in this breeding system compared to calves and were, therefore, more exposed to the common transmission routes, such as the mechanical vectors and contaminated fomites.

Also, the iELISA results indicated moderate exposure to B. bovis $(61.25 \% ; 245 / 400)$ and B. bigemina (51.25\%; 205/400) in the sampled beef cattle. Likewise, Barros et al. (2005) reported similar percentages of seropositivity to B. bovis (63.7\%) in among beef cattle in the municipality of Uauá, Bahia, northeastern Brazil. However, the iELISA seropositivity for B. bigemina in the Pantanal region was lower than that found $(90.5 \%$; 459/506) among beef cattle in Araguaína, Tocantins (Trindade et al., 2010). According to Mahoney \& Ross (1972), endemic stability areas for $B$. bovis and B. bigemina comprise those regions where the clinical illness incidence is low, and $75 \%$ of calves between 6 and 9 months of age are seropositive for Babesia spp. Although clinical cases of bovine babesiosis have not been 
diagnosed in the animals sampled in the present study, Pupin et al. (2019) reported 41 clinical cases and anatomopathological lesions of 33 babesiosis outbreaks by $B$. bovis in Zebu cattle of all age groups in the state of Mato Grosso do Sul in the 1995-2017 period.

The Chi-square test showed that calves were significantly $(P<0.05)$ more seropositive for the studied agents than cows, i.e., the infection frequency was higher for calves. It can be suggested that because the immune system of calves is not yet fully developed, they become, therefore, more susceptible to the infestation by the $B$. bovis vector tick. It is known that Nellore cattle have innate resistance against the fixation of the $R$. microplus tick to the skin, which is avoided by licking (Veríssimo et al., 2015). Thus, it is also hypothesized that calves have lower licking reflex compared to cows, thus allowing a higher number of fixed larvae and nymphs, which would have the sporogenic cycle of $B$ bovis and B. bigemina, respectively, activated in their salivary glands (Jalovecka et al., 2018). The moderate correlation found among co-seropositive animals for $A$. marginale $x$ $B$. bovis $\times B$. bigemina, is probably due to the constant presence of the $R$. microplus tick in the herds, the biological vector common to all three agents. Furthermore, calves had a higher co-seropositivity for $T$. vivax $\times$ A. marginale $\times$ B. bovis $\times B$. bigemina, which may be related especially to the developing immune system, in addition to contact with common transmission pathways of these agents. The seropositivity of both cows and calves was related to the farm studied, which can be explained by the sanitary conditions of each property, presence of ticks, hematophagous dipterans and reuse of needles.

The beef cattle sampled in the present study showed low exposure to C. burnetti. In fact, there are few available data on the serological occurrence of this agent in cattle in Brazil. Recently, Zanatto et al. (2019a) conducted the first study showing C. burnetii as a pathogen associated with infectious bovine rhinotracheitis and bovine viral diarrhea, N. caninum, Leptospira spp., T. gondii and $T$. vivax in cattle presenting reproductive disorders in Brazil and reported seropositivity of $13.7 \%$ (14/102) among the sampled animals. Coxiella burnetii spreads in the herds via aerosol and is commonly related to the extensive farming system (Parker et al., 2006), although ingesting contaminated food and bites of infected ticks are also defined as alternative transmission routes (Eldin et al., 2017). In this sense, the extensive farming system would favor the parasite transmission, mainly via aerosols from urine, feces, and secretions of the infected animals. Considering that the extensive production of livestock predominates in the study region, it is suggested that the concentration of the agent per $\mathrm{m}^{2}$ is low, decreasing the risk of transmission among the animals.

However, it is important to keep in mind that the Small Cell Variant (SCV), the resistant form of $C$. burnetii can survive for long periods in the environment (Coleman et al., 2004). Zanatto et al. (2019b) demonstrated the first serological evidence of exposure to C. burnetii $(5.32 \%, 7 / 169)$ of free-living cervids (Mazama gouazoubira and Blastocerus dichotomous) in Latin America, warning about its importance for an eventual Q fever epidemiology. Interestingly, some of the cervids seropositive for $C$. burnetii were sampled in the Pantanal Brazilian wetland, allowing to raise the possibility that the parasite may be disseminated in the region, despite the low seropositivity found. Furthermore, IFAT detects IgG antibodies against $C$. burnetii in phase I, commonly found during the chronic phase of the disease (Peacock et al., 1983), indicating the possibility that such animals may be infected. Nevertheless, it is not possible to discard the possibility of cross-reaction with other pathogens (Zanatto et al., 2019b).

Also, the IFAT results indicated low seropositivity for $A$. phagocytophilum in the studied cattle. Sacchi et al. (2012) also found seropositivity (16.78\%) for A. phagocytophilum by IFAT in Pantanal deer (B. dichotomous) sampled in the flooded areas of the Paraná River due to the construction of the Porto Primavera hydroelectric plant. However, phylogenetic analysis positioned the found Anaplasma sp. genotype close to Anaplasma platys. Ebani \& Bertelloni (2014) reported that cross-serological reaction with other 
species of Anaplasma and Ehrlichia could generate false-positive results for A. phagocytophilum in IFAT. It is known that the A. phagocytophilum transmission and distribution are related to the presence of vector ticks of the genus Ixodes spp., present only in the USA, Europe, and Asia (Woldehiwet, 2010; Sacchi et al., 2012). The absence of vector ticks in Brazil suggests that seropositivity for A. phagocytophilum of a single sample may result from a cross-reaction with another species of Anaplasma spp. circulating in cattle in the Brazilian territory. Since cervids and beef cattle under extensive farming system can divide the same grazing area in the Pantanal, it is probable that cattle herds are being exposed to the Anaplasma spp. genotype detected in cervids.

\section{Conclusion}

The present study revealed that the beef cattle in the Brazilian Pantanal are exposed to tick-borne agents (A. marginale, B. bovis, B. bigemina, C. burnetii, and A. phagocytophilum) and $T$. vivax. The high seropositivity correlation for $A$. marginale $\times B$. bovis $\times B$. bigemina is probably due to the presence of the tick biological vector, $R$. microplus in the studied farms. Common transmission pathways, mediated by hematophagous dipterans and fomites, explain the high co-seropositivity of cows for $A$. marginale and $T$. vivax. Low seropositivity to $C$. burnetii is probably due to the type of breeding system employed (extensive). Seropositivity for $A$. phagocytophilum in only one animal suggests the occurrence of a cross-serological reaction with another agent of the genus Anaplasma.

\section{Acknowledgements}

To the Graduate Program in Veterinary Medicine, Area of Concentration in Animal Pathology (Universidade Estadual Paulista, Unesp, Campus Jaboticabal), the FAPESP (Foundation for Research Support of the State of São Paulo - Process 2018/02753-0), FUNDECT (Foundation for Support to the Development of Education, Science and Technology of the State of Mato Grosso do Sul, Case 59 / 300.187 / 2016) and CNPq for financial support for this research (2014 / 401.403.120.16-5) and for the Productivity Grant granted to the MRA (CNPq Process No. 302420 / 2017-7). The present study was carried out with the support of the Coordination for the Improvement of Higher Education (CAPES - Code 1).

\section{References}

Alho CJR. The Pantanal. In: Fraser LH, Keddy PA. The world's largest Wetlands: Ecology and conservation. Ohio: Cambridge University Press; 2005. p. 203-271. https://doi.org/10.1017/CBO9780511542091.008.

Andrade GM, Machado RZ, Vidotto MC, Vidotto O. Immunization of bovines using a DNA vaccine (pcDNA3.1/MSP1b) prepared from the Jaboticabal strain of Anaplasma marginale. Ann N Y Acad Sci 2004; 1026(1): 257-266. http://dx.doi.org/10.1196/annals.1307.040. PMid:15604503.

Andrade Neto AQ, Mendonça CL, Souto RJC, Sampaio PH, Fidelis OL Jr, André MR, et al. Diagnostic, Clinical and Epidemiological aspects of dairy cows naturally infected by Trypanosoma vivax in the states of Pernambuco and Alagoas, Brazil. Braz J Vet Med 2019; 41: 1-15. http://dx.doi.org/10.29374/2527-2179.bjvm094319.

Aquino LPCT, Machado RZ, Alessi AC, Marques LC, Castro MB, Malheiros EB. Clinical, parasitological and immunological aspects of experimental infection with Trypanosoma evansi in dogs. Mem Inst Oswaldo Cruz 1999; 94(2): 255-260. http://dx.doi.org/10.1590/S0074-02761999000200025. PMid:10224539.

Atif FA. Anaplasma marginale and Anaplasma phagocytophilum: rickettsiales pathogens of veterinary and public health significance. Parasitol Res 2015; 114(11): 3941-3957. http://dx.doi.org/10.1007/s00436-015-4698-2. PMid:26346451.

Barros SL, Madruga CR, Araújo FR, Menk CF, Almeida MAO, Melo EPS, et al. Serological survey of Babesia bovis, Babesia bigemina, and Anaplasma marginale antibodies in cattle from the semi-arid 
region of the state of Bahia, Brazil, by enzyme-linked immunosorbent assays. Mem Inst Oswaldo Cruz 2005; 100(6): 513-517. http://dx.doi.org/10.1590/S0074-02762005000600003. PMid:16302060.

Bastos TSA, Faria AM, Madrid DMC, Bessa LC, Linhares GFC, Fidelis OLJ Jr, et al. First outbreak and subsequent cases of Trypanosoma vivax in the state of Goias, Brazil. Rev Bras Parasitol Vet 2017; 26(3): 366-371. http://dx.doi.org/10.1590/s1984-29612017019. PMid:28678894.

Batista JS, Riet-Correa F, Teixeira MM, Madruga CR, Simões SD, Maia TF. Trypanosomiasis by Trypanosoma vivax in cattle in the Brazilian semiarid: description of an outbreak and lesions in the nervous system. Vet Parasitol 2007; 143(2): 174-181. http://dx.doi.org/10.1016/j.vetpar.2006.08.017. PMid:16965857.

Cadioli FA, Barnabé PA, Machado RZ, Teixeira MCA, André MR, Sampaio PH, et al. First report of Trypanosoma vivax outbreak in dairy cattle in São Paulo state, Brazil. Rev Bras Parasitol Vet 2012; 21(2): 118-124. http://dx.doi.org/10.1590/S1984-29612012000200009. PMid:22832751.

Cançado PH, Piranda EM, Mourão GM, Faccini JL. Spatial distribution and impact of cattle-raising on ticks in the Pantanal region of Brazil by using the CO(2) tick trap. Parasitol Res 2008; 103(2): 371377. http://dx.doi.org/10.1007/s00436-008-0982-8. PMid:18454288.

Carrade DD, Foley JE, Borjesson DL, Sykes JE. Canine granulocytic anaplasmosis: a review. J Vet Intern Med 2004; 23(6): 1129-1141. http://dx.doi.org/10.1111/j.1939-1676.2009.0384.x. PMid:19761477.

Coleman SA, Fischer ER, Howe D, Mead DJ, Heinzen RA. Temporal analysis of Coxiella burnetii morphological differentiation.J Bacteriol 2004; 186(21): 7344-7352. http://dx.doi.org/10.1128/JB.186.21.7344-7352.2004. PMid:15489446.

De Mello VVC, Souza Ramos IA, Herrera HM, Mendes NS, Calchi AC, Campos JBV, et al. Occurrence and genetic diversity of hemoplasmas in beef cattle from the Brazilian Pantanal, an endemic area for bovine trypanosomiasis in South America. Comp Immunol Microbiol Infect Dis 2019; 66: 101337. http://dx.doi.org/10.1016/j.cimid.2019.101337. PMid:31437678.

Dumler JF, Barbet AF, Bekker CPJ, Dasch DA, Palmer GH, Ray SC, et al. Reorganization of genera in the families Rickettsiaceae and Anaplasmataceae in the order Rickettsiales: unification of some species of Ehrlichia with Anaplasma, Cowdria with Ehrlichia and Ehrlichia with Neorickettsia, descriptions of six new species combinations and designation of Ehrlichia equi and 'HGE agent' as subjective synonyms of Ehrlichia phagocytophila. Int J Syst Evol Microbio/ 2001; 51(Pt6): 2145-2165. https://doi.org/10.1099/00207713-51-6-2145PMID:11760958.

Ebani W, Bertelloni F. Serological evidence of exposure to Ehrlichia canis and Anaplasma phagocytophilum in Central Italian healthy domestic cats. Ticks Tick Borne Dis 2014; 5(6): 668-671. http://dx.doi.org/10.1016/j.ttbdis.2014.04.019. PMid:25113987.

Eldin C, Mélenotte C, Mediannikov O, Ghigo E, Million M, Edouard S, et al. From Q fever to Coxiella burnetii infection: A paradigm change. Clin Microbiol Rev 2017; 30(1): 115-190. http://dx.doi.org/10.1128/CMR.00045-16. PMid:27856520.

Fantin-Cruz I. Dinâmica da inundação em mesoescala na planície de inundação do rio Cuiabá - Brasil [dissertação]. Cuiabá: Universidade Federal de Mato Grosso; 2008.

Fereig RM, Mohamed SGA, Mahmoud HYAH, AbouLaila MR, Guswanto A, Nguyen TT, et al. Seroprevalence of Babesia bovis, B. bigemina, Trypanosoma evansi, and Anaplasma marginale antibodies in cattle in southern Egypt. Ticks Tick Borne Dis 2017; 8(1): 125-131. http://dx.doi.org/10.1016/j.ttbdis.2016.10.008. PMid:27789159.

Georgiev M, Afonso A, Neubauer H, Needham H, Thiery R, Rodolakis A, et al. Q fever in humans and farm animals in four European countries, 1982 to 2010. Euro Surveill 2013; 18(8): 20407. PMid:23449232.

González LF, García JA, Nuñez C, Perrone C, González-Baradat TM, Gonzatti B, et al. Trypanosoma vivax: a novel method for purification from experimentally infected sheep blood. Exp Parasitol 2005; 111(2): 126-129. http://dx.doi.org/10.1016/j.exppara.2005.05.008. PMid:16023641.

Guimarães JH, Tucci EC, Barros-Batttesti DM. Ectoparasitos de importância veterinária. São Paulo: Editora Plêiade; 2001.

Herrera C, Bargues MD, Fajardo A, Montilla M, Triana O, Vallejo GA, et al. Identifying four Trypanosoma cruzi isolate haplotypes from different geographic regions in Colombia. Infect Genet Evo/ 2007; 7(4): 535-539. http://dx.doi.org/10.1016/j.meegid.2006.12.003. PMid:17287152. 
Ismail N, McBride JW. Tick-Borne emerging infections: ehrlichiosis and anaplasmosis. Clin Lab Med 2017; 37(2): 317-340. http://dx.doi.org/10.1016/j.cll.2017.01.006. PMid:28457353.

Jalovecka M, Hajdusek O, Sojka D, Kopacek P, Malandrin L. The complexity of piroplasms life cycles. Front Cell Infect Microbiol 2018; 8: 248. http://dx.doi.org/10.3389/fcimb.2018.00248. PMid:30083518.

Kocan KM, de La Fuente J, Guglielmone AA, Meléndez RD. Antigens and alternatives for control of Anaplasma marginale infection in cattle. Clin Microbiol Rev 2003; 16(4): 698-712. http://dx.doi.org/10.1128/CMR.16.4.698-712.2003. PMid:14557295.

Lappin MR. Update on flea and tick associated diseases of cats. Vet Parasitol 2018; 254: 26-29. http://dx.doi.org/10.1016/j.vetpar.2018.02.022. PMid:29657007.

Machado RZ, Montassier HJ, Pinto AA, Lemos EG, Machado MRF, Valadão IFF, et al. An enzyme-linked immunosorbent assay (ELISA) for the detection of antibodies against Babesia bovis in cattle. Vet Parasitol 1997; 71(1): 17-26. http://dx.doi.org/10.1016/S0304-4017(97)00003-4. PMid:9231985.

Mahoney DF, Ross DR. Epizootiological factors in the control of bovine babesiosis. Aust Vet J 1972; 48(5): 292-298. http://dx.doi.org/10.1111/j.1751-0813.1972.tb05160.x. PMid:4672119.

Marcelino I, Almeida AM, Ventosa M, Pruneau L, Meyer DF, Martinez D, et al. Tick-borne diseases in cattle: applications of proteomics to develop new generation vaccines. J Proteomics 2012; 75(14): 4232-4250. http://dx.doi.org/10.1016/j.jprot.2012.03.026. PMid:22480908.

Martins TM, Neves L, Pedro OC, Fafetine JM, Rosário VE, Domingos A. Molecular detection of Babesia spp. and other haemoparasitic infections of cattle in Maputo Province, Mozambique. Parasitology 2010; 137(6): 939-946. http://dx.doi.org/10.1017/S003118200999196X. PMid:20128941.

Maurin M, Raoult DF. Q fever. Clin Microbiol Rev 1999; 12(4): 518-553. http://dx.doi.org/10.1128/CMR.12.4.518. PMid:10515901.

Mendes NS, Souza Ramos IA, Herrera HM, Campos JBV, Almeida Alves JV, Macedo GC, et al. Genetic diversity of Babesia bovis in beef cattle in a large wetland in Brazil. Parasitol Res 2019; 118(7): 2027 2040. http://dx.doi.org/10.1007/s00436-019-06337-3. PMid:31079252.

Myers N, Mittermeier RA, Mittermeier CG, Fonseca GAB, Kent J. Biodiversity hotspots for conservation priorities. Nature 2000; 403(6772): 853-858. http://dx.doi.org/10.1038/35002501. PMid:10706275.

Oliveira MC, Alencar MM, Giglioti R, Beraldo MC, Aníbal FF, Correia RO, et al. Resistance of beef cattle of two genetic groups to ectoparasites and gastrointestinal nematodes in the state of São Paulo, Brazil. Vet Parasitol 2013; 197(1-2): 168-175. http://dx.doi.org/10.1016/j.vetpar.2013.06.021. PMid:23916059.

Pacheco RC, Echaide IE, Alves RN, Beletti ME, Nava S, Labruna MB. Coxiella burnetii in ticks, Argentina. Emerg Infect Dis 2013; 19(2): 344-346. http://dx.doi.org/10.3201/eid1902.120362. PMid:23343647.

Parker NR, Barralet JH, Bell AM. Q fever. Lancet 2006; 367(9511): 679-688. http://dx.doi.org/10.1016/S0140-6736(06)68266-4. PMid:16503466.

Peacock MG, Philip RN, Williams JC, Faulkner RS. Serological evaluation of O fever in humans: enhanced phase I titers of immunoglobulins $\mathrm{G}$ and $\mathrm{A}$ are diagnostic for $\mathrm{Q}$ fever endocarditis. Infect Immun 1983; 41(3): 1089-1098. http://dx.doi.org/10.1128/IAI.41.3.1089-1098.1983. PMid:6885155.

Pupin RC, Guizelini CC, Lemos RAA, Martins TB, Borges FA, Borges DGL, et al. Retrospective study of epidemiological, clinical and pathological findings of bovine babesiosis in Mato Grosso do Sul, Brazil (1995-2017). Ticks Tick Borne Dis 2019; 10(1): 36-42. http://dx.doi.org/10.1016/j.ttbdis.2018.08.015. PMid:30196016.

Reeves WK, Loftis AD, Sanders F, Spinks MD, Wills W, Denison AM, et al. Borrelia, Coxiella and Rickettsia in Carios capensis (Acari: Argasidae) from a brown pelican (Pelecanus occidentalis) rookery in South Carolina, USA. Exp App/ Acaro/ 2006; 39(3-4): 321-329. http://dx.doi.org/10.1007/s10493-006-90127. PMid:16821092.

Sacchi ABV, Duarte JMB, André MR, Machado RZ. Prevalence and molecular characterization of Anaplasmataceae agents in free-ranging Brazilian marsh deer (Blastocerus dichotomus). Comp Immunol Microbiol Infect Dis 2012; 35(4): 325-334. http://dx.doi.org/10.1016/j.cimid.2012.02.001. PMid:22381686.

Saleem S, ljaz M, Farooqi SH, Ghaffar A, Ali K, Iqbal K, et al. Equine granulocytic anaplasmosis 28 years later. Microb Pathog 2018; 119: 1-8. http://dx.doi.org/10.1016/j.micpath.2018.04.001. PMid:29626656. 
Sampaio PH, Fidelis OL Jr, Marques LC, Machado RZ, Barnabé PA, André MR, et al. Acute-phase protein behavior in dairy cattle herd naturally infected with Trypanosoma vivax. Vet Parasito/ 2015; 211(3-4): 141-145. http://dx.doi.org/10.1016/j.vetpar.2015.05.014. PMid:26012859.

Scorpio DG, Caspersen K, Ogata H, Park J, Dumler JS. Restricted changes in major surface protein-2 (msp2) transcription after prolonged in vitro passage of Anaplasma phagocytophilum. BMC Microbiol 2004; 4(1): 1. http://dx.doi.org/10.1186/1471-2180-4-1. PMid:14713314.

Silva JB, André MR, Machado RZ. Low genetic diversity of Anaplasma marginale in calves in an endemic area for bovine anaplasmosis in the state of São Paulo, Brazil. Ticks Tick Borne Dis 2016; 7(1): 20-25. http://dx.doi.org/10.1016/j.ttbdis.2015.07.018. PMid:26318264.

Silva RAMS, Silva JA, Schneider RC, Freitas J, Mesquita D, Mesquita T, et al. Outbreak of Trypanosomiasis due to Trypanosoma vivax (Ziemann, 1905) in bovines of the Pantanal, Brazil. Mem Inst Oswaldo Cruz 1996; 91(5): 561-562. http://dx.doi.org/10.1590/S0074-02761996000500005. PMid:9137742.

Singh H, Mishra AK, Rao JR, Tewari AK. Comparison of indirect fluorescent antibody test (IFAT) and slide enzyme linked immunosorbent assay (SELISA) for diagnosis of Babesia bigemina infection in bovines. Trop Anim Health Prod 2009; 41(2): 153-159. http://dx.doi.org/10.1007/s11250-008-9170-1. PMid:19115088.

Sousa KC, André MR, Herrera HM, Andrade GB, Jusi MM, Santos LL, et al. Molecular and serological detection of tick-borne pathogens in dogs from an area endemic for Leishmania infantum in Mato Grosso do Sul, Brazil. Rev Bras Parasitol Vet 2013; 22(4): 525-531. http://dx.doi.org/10.1590/S198429612013000400012. PMid:24473877.

Souza Ramos IA, Herrera HM, Fernandes SJ, Amaral RB, Zanatto DCS, Silva TMV, et al. Genetic diversity of Anaplasma marginale in beef cattle in the Brazilian Pantanal. Ticks Tick Borne Dis 2019b; 10(4): 805-814. http://dx.doi.org/10.1016/j.ttbdis.2019.03.015. PMid:30930114.

Souza Ramos IA, Herrera HM, Mendes NS, Fernandes SJ, Campos JBV, Alves JVA, et al. Phylogeography of $m s p 4$ genotypes of Anaplasma marginale in beef cattle from the Brazilian Pantanal. Rev Bras Parasitol Vet 2019a; 28(3): 451-457. http://dx.doi.org/10.1590/s1984-29612019049. PMid:31390434.

Stuen S, Granquist EG, Silaghi C. Anaplasma phagocytophilum a widespread multi-host pathogen with highly adaptive strategies. Front Cell Infect Microbiol 2013; 3: 31. http://dx.doi.org/10.3389/fcimb.2013.00031. PMid:23885337.

Trindade HI, Silva GRA, Teixeira MCA, Sousa MG, Machado RZ, Freitas FLC, et al. Detection of antibodies against Babesia bovis and Babesia bigemina in calves from the region of Araguaína, State of Tocantins, Brazil. Rev Bras Parasitol Vet 2010; 19(3): 169-173. http://dx.doi.org/10.1590/S198429612010000300008 . PMid:20943021.

Veríssimo CJ, D'Agostino SM, Pessoa FF, Toledo LM, Santos IKFM. Length and density of filiform tongue papillae: differences between tick-susceptible and resistant cattle may affect tick loads. Parasit Vectors 2015; 8(1): 1-10. http://dx.doi.org/10.1186/s13071-015-1196-4. PMid:26573922.

Woldehiwet Z. The natural history of Anaplasma phagocytophilum. Vet Parasitol 2010; 167(2-4): 108-122. http://dx.doi.org/10.1016/j.vetpar.2009.09.013. PMid:19811878.

World Organization for Animal Health - OIE. Infectious bovine rhinotracheitis/infectious pustular vulvovaginitis. In: World Organization for Animal Health - OIE. Manual of Diagnostics Tests and Vaccines for Terrestrial Animals [online] Paris: OIE; 2018 [cited 2019 Nov 24]. Available from: http://www.oie.int/fileadmin/Home/eng/Health_standards/tahm/3.04.11_IBR_IPV.pdf

Zanatto DCS, Duarte JMB, Labruna MB, Tasso JB, Calchi AC, Machado RZ, et al. Evidence of exposure to Coxiella burnetii in neotropical free-living cervids in South America. Acta Trop 2019a; 22(197): 105037. http://dx.doi.org/10.1016/j.actatropica.2019.05.028. PMid:31128095.

Zanatto DCS, Gatto IRH, Labruna MB, Jusi MMG, Samara SI, Machado RZ, et al. Coxiella burnetii associated with BVDV (Bovine Viral Diarrhea Virus), BoHV (Bovine Herpesvirus), Leptospira spp., Neospora caninum, Toxoplasma gondii and Trypanosoma vivax in reproductive disorders in cattle. Rev Bras Parasitol Vet 2019b; 28(2): 245-257. http://dx.doi.org/10.1590/s1984-29612019032. PMid:31215610. 